\title{
Penguatan Kelompok Tani Berbasis Produksi dan Agrowisata Kopi di Kecamatan Way Ratai, Kabupaten Pesawaran, Lampung
}

\section{(Farmer Group Strengthening Based on Coffee Production and Agrotourism in Way Ratai Subdistrict, Pesawaran District, Lampung)}

\author{
Rusdi Evizal1* ${ }^{*}$ Fembriarti Erry Prasmatiwi², Sarno $^{3}$, Otik Nawansih4, \\ Dedy Miswar ${ }^{5}$, Liska Mutiara Septiana ${ }^{3}$ \\ ${ }^{1}$ Jurusan Agroteknologi, Fakultas Pertanian, Universitas Lampung, Jalan Sumantri Brojonegoro No 1, \\ Bandar Lampung 35145. \\ 2 Jurusan Agribisnis, Fakultas Pertanian, Universitas Lampung, Jalan Sumantri Brojonegoro No 1, Bandar Lampung 35145. \\ 3 Jurusan Ilmu Tanah, Fakultas Pertanian, Universitas Lampung, Jalan Sumantri Brojonegoro No 1 , \\ Bandar Lampung 35145. \\ 4 Jurusan Teknologi Hasil Pertanian, Fakultas Pertanian, Universitas Lampung, Jalan Sumantri Brojonegoro No 1, \\ Bandar Lampung 35145. \\ 5 Jurusan Pendidikan Ilmu Pengetahuan Sosial, Fakultas Keguruan dan Ilmu Pendidikan, Universitas Lampung \\ Jalan Sumantri Brojonegoro No 1 Bandar Lampung 35145 \\ *Penulis Korespondensi: rusdi.evizal@fp.unila.ac.id \\ Diterima Maret 2020/Disetujui Januari 2021
}

\begin{abstract}
ABSTRAK
Propinsi Lampung merupakan sentra produksi kopi Robusta sedangkan kopi Arabika mulai dikembangkan di daerah pegunungan antara lain di Desa Harapan Jaya, Kecamatan Way Ratai, Kabupaten Pesawaran. Desa ini merupakan destinasi ekowisata dan juga memiliki potensi agrowisata perkebunan kopi. Tujuan kegiatan pengabdian kepada masyarakat (PKM) ini adalah: 1) Meningkatkan pengetahuan dan keterampilan anggota kelompok tani dalam agroteknologi kopi Arabika; 2) Meningkatkan produktivitas kebun kopi melalui pemeliharaan secara tepat; dan 3) Merumuskan model penguatan kelompok tani berbasis produksi dan agrowisata kopi. Kegiatan ini dilakukan di Kelompok Tani Karya Subur, Desa Harapan Jaya pada 2018-2019. Metode yang digunakan adalah penyuluhan, pelatihan, demplot, pendampingan, penguatan kelompok, dan diskusi lapangan pada anjangsana dan anjang karya. Hasil kegiatan ini menyimpulkan bahwa: 1) Kegiatan PKM ini meningkatkan pengetahuan dan keterampilan anggota kelompok tani dalam agroteknologi kopi Arabika; 2) Kegiatan PKM ini meningkatkan produktivitas kebun kopi demplot yang didampingi; dan 3) Model penguatan kelompok tani berbasis produksi dan agrowisata kopi adalah melalui peningkatan kapasitas kelompok dalam aktivitas eduwisata dan desawisata terkait dengan proses produksi kopi dari hulu ke hilir, peningkatan aksesibilitas dan fasilitas yang dikoordinasikan dengan aparat desa, serta peningkatan promosi agrowisata khususnya kepada lembaga pendidikan, profesi, dan komunitas.
\end{abstract}

Kata kunci: agrowisata, eduwisata, kopi Arabika, penguatan

\begin{abstract}
Lampung Province is the center of Robusta coffee production while Arabica coffee has begun to be developed in the area, including in Harapan Jaya Village, Way Ratai Subdistrict, District of Pesawaran. This village is an ecotourism destination and also has a potential of agrotourism, especially Arabica coffee farming. The objectives of the Community Service Activities are: 1) Increasing knowledge and skills of farmer group members in Arabica coffee agrotechnology; 2) increasing coffee plantation productivity through proper maintenance; and 3) Formulating a model of strengthening farmer group based on coffee agrotourism. This program was carried out at the Karya Subur Farmer Group, in Harapan Jaya Village in year 2018-2019. The methods used are discourse, training, demonstration plots, mentoring, and discussion. The results of this program conclude that: 1) Increasing the knowledge and skills of farmer group members in Arabica coffee agrotechnology; 2) Increasing productivity of coffee plantations plot belonging to the group members assisted; and 3) a model of strengthening of farmer groups based on coffee production and agrotourism is through increasing group capacity in tourism and tourism activities related to the coffee production process from upstream to downstream, increasing accessibility and facilities coordinated with village officials, and increasing agro tourism promotion especially to educational institutions, professionals, and communities.
\end{abstract}

Key words: agrotourism, Arabic coffee, edutourism, strengthening 


\section{PENDAHULUAN}

Kecamatan Way Ratai, Kabupaten Pesawaran, Lampung merupakan pemekaran Kecamatan Padang Cermin berdasarkan Perda No 12 Tahun 2014. Kecamatan ini memiliki luas wilayah $10.503,78$ ha, berada di Selatan Gunung Pesawaran, yaitu berbatasan dengan kawasan hutan Register 19 Taman Hutan Rakyat (Tahura) Wan Abdul Rahman. Kondisi geografi berupa pegunungan dengan elevasi 80-1.437 mdpl yang umumnya (39\%) penggunaan lahan berupa perkebunan rakyat (Pemkab Pesawaran 2017). Desa Harapan Jaya merupakan desa yang teratas berbatasan dengan kawasan hutan lindung dengan elevasi lebih dari 700 mdpl dengan kemiringan lahan agak curam sampai sangat curam yang didominasi dengan penggunaan lahan perkebunan (Miswar et al. 2018) antara lain cengkeh, kelapa, kopi, pala, dan yang terluas adalah perkebunan kakao. Pada Tahura Wan Abdul Rahman di Kecamatan Padang Cermin dan Way Ratai banyak ditanam kopi, kakao, dan cengkeh dengan sistem agroforestri (Hilmanto 2011).

Kecamatan Way Ratai memiliki akses jalan raya yang relatif mulus dari arah selatan-timur, yaitu sekitar $45 \mathrm{~km}$ dari Bandar Lampung (ibu kota propinsi) atau dari arah utara berjarak 35 km dari Gedung Tataan (ibu kota kabupaten). Perjalanan dari Bandar Lampung melewati wilayah pariwisata bahari berupa pantai dan pulau. Pada Kecamatan Way Ratai terdapat destinasi pariwisata alam berupa air terjun, yaitu Air terjun Anglo di Gunung Rejo, Air Terjun Kembar di Desa Ceringin Asri, Air Terjun Ciupang di Desa Sumberjaya, Air Terjun Banyu Mandiri di Desa Pesawaran Indah, Air Terjun Rindu Alam di Kali Rejo, dan Air Terjun Sinar Tiga di Desa Harapan Jaya (Pemkab Pesawaran 2017). Jalan menuju Air Terjun Sinar Tiga di Desa Harapan Jaya melewat wisata Pemandian Air Panas Way Urang. Air Terjun Sinar Tiga dikunjungi lebih dari 4 ribu orang per tahun (Mustofa et al. 2018).

Perkebunan kakao dan kopi sering ditumpangsarikan dengan berbagai tanaman seperti pisang, cengkeh, kelapa, lada, durian, dan pala yang menyumbang $10 \%$ dari pendapatan petani (Gusti et al. 2013). Kecamatan Way Ratai merupakan sentra perkebunan kakao, kopi, dan pala dengan luas masing-masing 4.125, 419, dan 34 ha (BPS Kabupaten Pesawaran 2018). Tahura Wan Abdul Rahman yang berlokasi di sebelah utara Kecamatan Way Ratai dan Padang Cermin memiliki banyak potensi wisata alam seperti air terjun dan sumber air panas serta potensi agrowisata perkebunan (kopi dan kakao) dan agrowisata buah seperti durian, duku, manggis, dan rambutan (Evizal \& Prasmatiwi 2011) yang dikelola petani yang tergabung dalam Gabungan Kelompok Pengelola dan Pelestari Hutan GKPPH pada blok pemanfaatan dengan sistem tanam agroforestri dan sistem pengelolaan kolaboratif dalam program yang disebut Pengelolaan Hutan Bersama Masyarakat (Mayasari et al. 2015).

Usaha agrowisata berbasis perkebunan kopi memiliki risiko ketidakpastian dan keterbatasan dalam pengembangan, sehingga diperlukan penguatan kelembagaan termasuk juga kelembagaan kelompok tani ataupun kelompok sadar wisata. Model pengembangan agrowisata kopi perlu mempertimbangkan peluang integrasi dengan usaha wisata lain seperti ekowisata, wisata minat khusus, wisata pendidikan dan desa wisata yang bersifat lintas wilayah sehingga terbentuk jaringan agroekowisata yang kuat (Dwiridotjahjono et al. 2017).

Anggota kelompok tani Karya Subur berjumlah 20 orang umumnya melakukan usaha tani kopi dan kakao baik di walayah desa dan sekitarnya maupun lintas kecamatan. Pada lahan di bawah ketinggian $700 \mathrm{~m}$, petani bertanam kakao dan kopi Robusta, pada ketinggian 700$1000 \mathrm{~m}$ petani bertanam kopi Robusta, sedangkan pada lahan yang lebih tinggi mencapai lebih 1.000 mdpl, petani bertanam kopi baik Robusta maupun Arabika karena tanaman kakao tidak memberikan hasil akibat elevasi yang terlalu tinggi dan angin berhembus kencang. Mulai tahun 2014 beberapa anggota kelompok tani sudah memulai mengusahakan kopi Arabika dan saat ini sudah mencapai 15 ha yang sebagian telah memberikan hasil dan dijual dalam bentuk kopi biji maupun kopi bubuk.

Tujuan kegiatan pengabdian kepada masyarakat ini adalah 1) Meningkatkan pengetahuan dan keterampilan anggota kelompok tani dalam agroteknologi kopi Arabika; 2) Meningkatkan produktivitas kebun kopi melalui pemeliharaan secara tepat; dan 3) Merumuskan model penguatan kelompok tani berbasis produksi dan agrowisata kopi.

\section{METODE PELAKSANAAN KEGIATAN}

\section{Lokasi dan Sasaran Program}

Kegiatan PKM berlokasi di Desa Harapan Jaya, Kecamatan Way Ratai, Kabupaten Pesawaran, Propinsi Lampung dengan sasaran adalah anggota Kelompok Tani Karya Subur. Anggota 
kelompok tani ini membudidayakan berbagai komoditas perkebunan seperti kopi Robusta, Arabika, Liberika, kakao, lada, dan pala sehingga sering menjadi tempat praktik mahasiswa. Selain itu, kebun anggota kelompok tani berdekatan dengan tiga loksi air terjun yang perlu dipromosikan sebagai destinasi pariwisata. Peta lokasi disajikan pada Gambar 1.

\section{Waktu Pelaksanaan}

Kegiatan PKM ini dilaksanakan pada AprilNovember 2019, sedangkan prasurvei dan pendampingan sudah dilakukan sejak April 2018. Hal ini terkait dengan teknis budi daya kopi sebagai tanaman tahunan dan musim buah kopi yang hanya sekali dalam setahun. Pemupukan dilaksanakan pada bulan Maret dan Oktober; penyambungan kopi dewasa dilakukan pada Februari-Maret. Panen, pemangkasan lepas panen, dan pascapanen dilakukan bulan JuniAgustus. Pembibitan dilaksanakan setelah panen biji, yaitu bulan September selama setahun sampai bibit siap tanam pada musim hujan tahun berikutnya.

\section{Metode Pelaksanaan Kegiatan}

Kegiatan penguatan kelompok dilakukan menggunakan berbagai metode yaitu penyuluhan, pelatihan, demplot, dan pendampingan sebagaimana disebutkan oleh Hermanto \& Swatika (2011). Penyuluhan dilaksanakan dengan penyampaian materi terutama terkait dengan usaha tani kopi Arabika yang sedang dikembangkan petani sebagai diversifikasi produk di samping kopi Robusta yang umum ditanam. Pelatihan dilakukan untuk meningkatkan keterampilan petani dalam teknis grafting interspesifik Arabika/Robusta, Arabika/Liberika, dan Robusta/Liberika. Demplot yang dibuat adalah demplot pembibitan kopi Arabika dan Liberika dan demplot intensifikasi kopi Arabika. Penguatan kelompok dilakukan dengan cara pendampingan dalam administrasi, analisis potensi, analisis masalah, penyusunan, dan evaluasi program

\section{HASIL DAN PEMBAHASAN}

\section{Pengembangan Kopi Arabika}

Penyuluhan dan pelatihan diikuti oleh pengurus dan anggota Kelompok Tani Karya Subur dimulai dengan presentasi, diskusi, FGD dan dilanjutkan dengan demonstrasi pembibitan kopi Arabika (Gambar 2). Dari FGD terungkap bahwa anggota kelompok semuanya berkebun kopi Robusta menggunakan varietas kopi lokal Kedondong. Produktivitas kopi lokal ini kurang memuaskan, yaitu kurang dari $6 \mathrm{kw} / \mathrm{ha} /$ tahun. Varietas lokal Kedondong merupakan varietas peninggalan perkebunan Belanda. Disarankan perlu adanya introduksi dan klonisasi

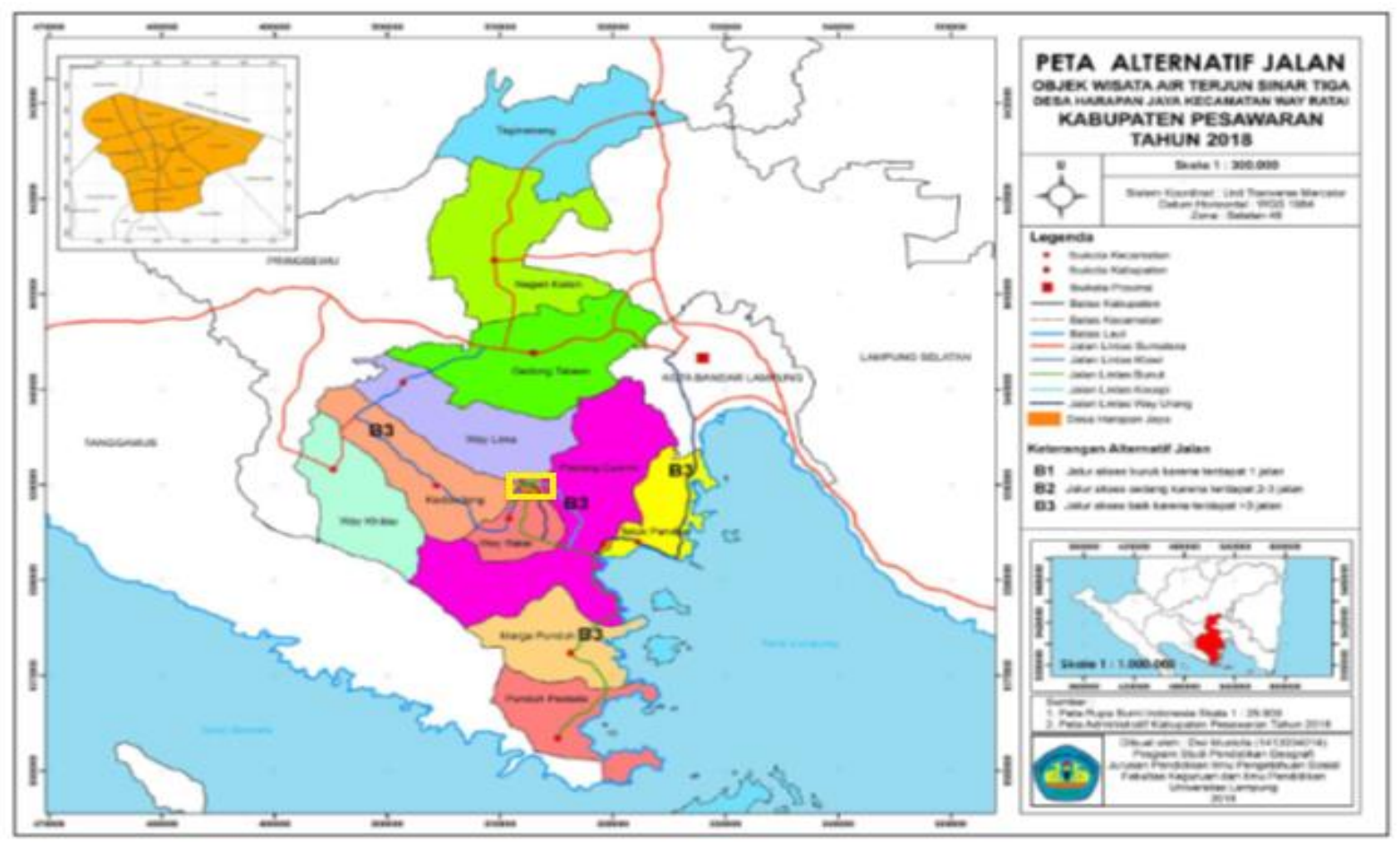

Gambar 1 Peta lokasi kegiatan pengabdian kepada masyarakat (kotak kuning) di Pesawaran. 


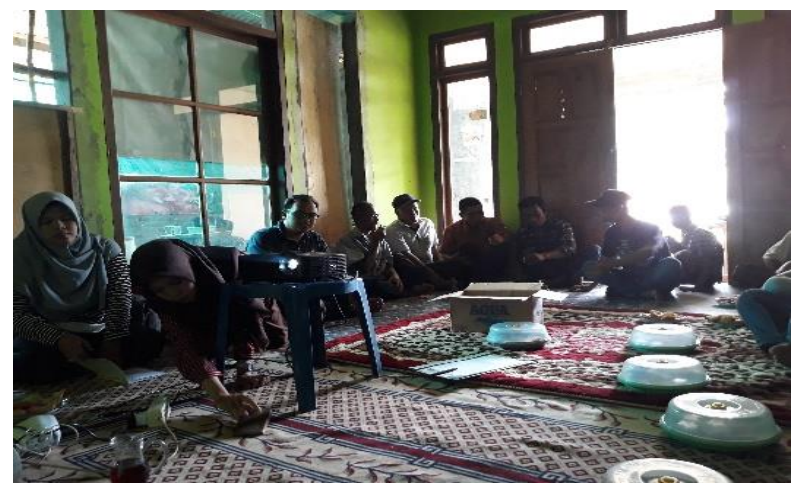

a

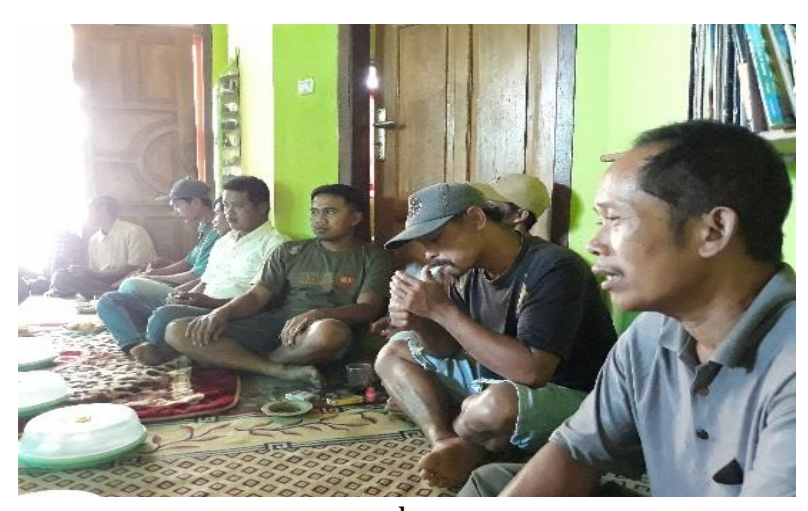

b

Gambar 2 a dan b) Penyuluhan pengembangan kopi Arabika dan agrowisata.

menggunakan klon unggul Lampung yang sudah dilepas oleh Pemerintah, yaitu klon Korolla 1, Korolla 2, Korolla 3, dan Korolla 4. Potensi produksi klon-klon ini berkisar 1,4-3,3 ton biji kering per ha.

Saat ini 10 anggota Kelompok Tani Karya Subur atau $50 \%$ dari anggota sudah berkebun kopi Arabika dengan luas total sekitar 15 ha, sebagian sudah berbuah dan panen 2-3 musim. Anggota kelompok lainnya, yaitu 10 orang (50\% anggota) semuanya ingin menanam kopi Arabika. Sebanyak $15 \%$ anggota belum sama sekali menanam kopi Arabika, dan sebanyak 35\% anggota sudah mulai menanam dan ingin memperluas lahan kopi Arabika. Untuk itu perlu pendampingan pembibitan kopi dalam hal pemilihan pohon induk. Selain itu petani berharap agar diintroduksi benih kopi Arabika dari luar, seperti dari Pusat Penelitian Kopi dan Kakao Jember, dari Lampung Barat, Semendo Sumsel, Medan, dan Aceh untuk perbandingan dengan varietas kopi Kartika yang sudah ditanam petani. PKM ini telah melakukan introduksi varietas kopi Arabika Sigararutang dari Medan, Arabika Andungsari 2K dan Komasti dari Puslit Koka Jember, dan kopi Liberika varietas Libtukom.

Kegiatan pelatihan pembibitan kopi Arabika dilakukan dengan demonstrasi penyemaian benih kopi Sigararutang mulai dari penyiapan media pasir, seleksi benih dan penyemaian di bak penyemaian. Hasil semaian dipindah di polibag sebagai demplot pembibitan kopi (Gambar 3). Bibit hasil semaian di kotak, pada umur 2 bulan dipindahtanam di polibag yang sudah disiapkan dan disusun di bawah naungan paranet plastik. Sebagai media, polibag diisi dengan tanah atas dicampur dengan bahan organik seperti pupuk kandang dan biochar kulit kopi. Petani umumnya mempunyai ternak kambing atau sapi yang dapat dimanfaatkan sebagai campuran media tanam. Sementara untuk memperbaiki sifat fisik media semai dapat diberikan kulit kopi dicampur biochar yang dibuat dari limbah kulit kopi.

Setiap pekebun kopi menghasilkan limbah kulit kopi, yaitu sisa penggilingan kopi glondong menjadi kopi yang dilaksanakan di samping rumah. Bahan ini umumnya dibiarkan sebagai limbah sehingga perlu dimanfaatkan untuk budi daya kopi, yaitu dikembalikan ke kebun kopi sebagai bahan organik, campuran media tanam, atau bahan untuk membuat biochar. Biochar banyak manfaatnya antara lain sebagai amandemen untuk meningkatkan kesuburan tanah dan juga dapat digunakan sebagai campuran media tanam, baik penyemaian kopi maupun tanaman lainnya.

Persiapan demplot dimulai pada bulan Januari 2019 dengan melakukan penyiangan gulma secara manual, diikuti pemupukan $50 \%$ dosis (Tabel 1) dilakukan pada bulan Mei ketika buah kopi mulai masak untuk mendorong tumbuhnya percabangan baik cabang buah B0, B1, dan B2 (cabang belum berbuah, cabang sedang berbuah 1 kali, dan cabang berbuah kedua kali). Pemupukan kedua dilaksanakan pada akhir bulan Oktober ketika bunga sudah banyak muncul dan mekar, yaitu bertujuan untuk mendorong pembuahan, pengisian buah, dan mencegah kerontokan buah.

Kegiatan PKM ini berhasil meningkatkan pengetahuan dan keterampilan petani dalam membudidayakan kopi Arabika di Kelompok Tani Karya Subur. Hasil evaluasi yang dipilih dari 12 indikator pengetahuan dan keterampilan menunjukkan peningkatan skor 36 menjadi 51 yang menunjukkan tingkat pengetahun/keterampilan meningkat dari kategori cukup menjadi baik. Produktivitas kebun demplot kopi Arabika tahun musim 2019/2020 meningkat dibandingkan dengan tahun 2018/2019, yaitu dari 0,6 ton/ha menjadi 1,1 ton/ha (Gambar 4). Dari hasil diskusi terungkap bahwa adanya kegiatan PKM 


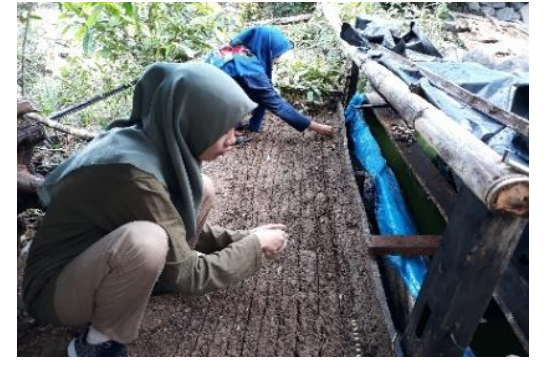

a

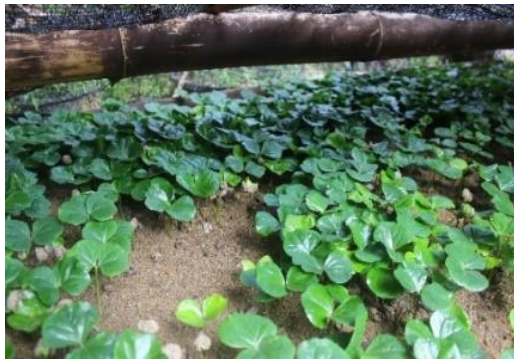

b

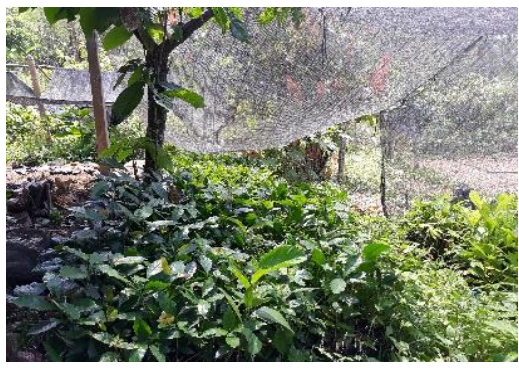

C

Gambar 3 a, b, dan c) Demplot pembibitan kopi.

Tabel 1 Pemeliharaan demplot

\begin{tabular}{ll}
\hline \multicolumn{1}{c}{ Tindakan pemeliharaan } & \multicolumn{1}{c}{ Uraian } \\
\hline Pemupukan & Urea 2 ku/ha, Phonska 2 ku/ha, Mutiara 1ku/ha, KCl 1ku/ha \\
Pengendalian gulma & Kored manual 4 kali/tahun \\
Pemangkasan cabang kopi & $2 \times /$ setahun (PLP dan pemeliharaan) \\
Penyambungan & - Arabika Kartika/Robusta sambung ortotrop \\
& - Arabika Andungsari/Robusta sambung plagiotrop \\
& - Arabika Andungsari 2K/Arabika Kartika \\
\hline
\end{tabular}

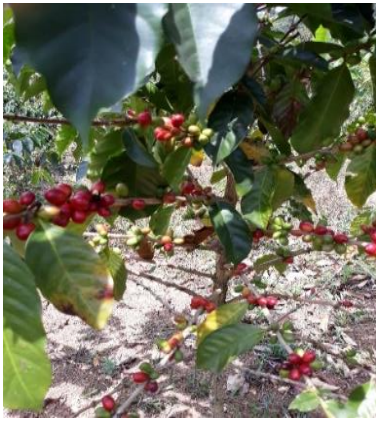

a

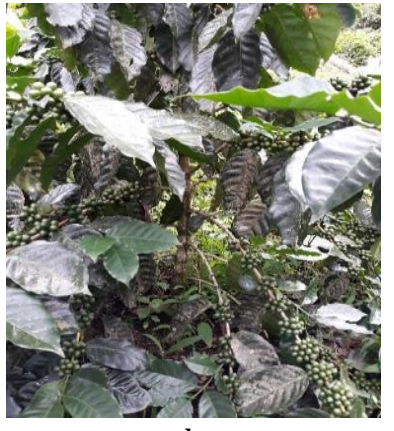

b

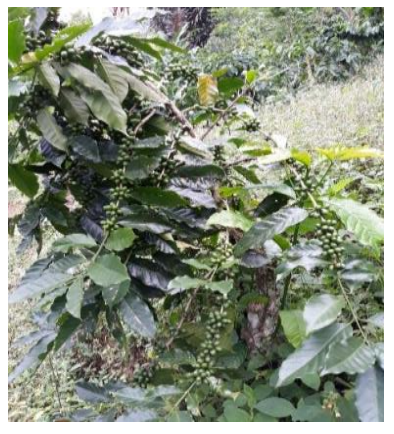

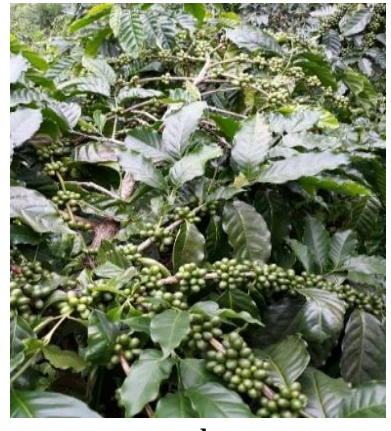

d

Gambar 4 Peningkatan produktivitas plot binaan: a) Non binaan; b) Arabika/Arabika Lancuran; c) Arabika/ Robusta Lancuran; dan d) Arabika/Robusta tak-ent di mana cabang Robusta tetap dipertahankan.

ini meningkatnya minat petani anggota kelompok tani mitra dan anggota kelompok tani sekitar bahkan di luar desa untuk berusahatani kopi Arabika. PKM ini menyarankan 2 pola perluasan areal, yaitu penanaman baru dan pola konversi atau rehabilitasi dengan cara klonisasi Arabika pada tegakan kopi Robusta (grafting interspesifik Arabika/Robusta). Penyambungan kopi intraspesifik Robusta/Robusta dan interspesifik Robusta/Liberika serta Arabika/Robusta merupakan kearifan lokal etnoagronomi yang dikembangkan petani kopi di Lampung (Evizal 2013; Evizal \& Prasmatiwi 2020). Hasil PKM ini menunjukkan bahwa penyambungan interspesifik Arabika/Robusta yang disertai intensifikasi pemeliharaan terbukti dapat meningkatkan produktivitas.

Permintaan bahan tanam kopi Arabika meningkat, berupa benih yang diseleksi dari pohon induk unggul, bibit polibag yang dikembangkan oleh kelompok, entres, maupun bibit cabutan dari kebun produksi. Kelompok tani perlu berperan dalam menyediakan bahan tanam kopi dan tanaman lainnya seperti kakao, pala dan alpukad untuk anggota kelompok maupun dijual untuk umum. Desa Harapan Jaya, Kecamatan Way Ratai dalam beberapa tahun kedepan sangat berpotensi menjadi salah satu sentra unggulan produksi kopi Arabika di Lampung.

\section{Penguatan Kelompok Tani Berbasis Agrowisata Kopi}

Model penguatan kelompok mengoptimalkan potensi sebagai sentra produksi kopi dan tanaman lainnya dengan potensi sebagai destinasi agrowisata. Rumusan pilar penguatan kelompok berbasis kopi dan agrowisata adalah a) Peningkatan produksi kopi; b) Peningkatan kapasitas kelompok dalam aktivitas eduwisata dan desa wisata terkait dengan proses produksi kopi dari hulu ke hilir; c) Peningkatan aksesibilitas dan fasilitas yang dikoordinasikan dengan aparat 
desa; dan d) peningkatan promosi agrowisata khususnya kepada lembaga pendidikan, profesi, dan komunitas.

Desa Harapan Jaya memiliki potensi agrowisata yang didukung oleh potensi alam kaki gunung yang indah berupa puncak gunung dan pemandangan lepas ke dataran bawah, hawa yang sejuk, air terjun yang melewati permandian air panas, persawahan, ladang sayur, dan perkebunan rakyat, yaitu perkebunan kopi Robusta, kopi Arabika, kakao, pala, lada, dan cengkeh. Sebagai destinasi wisata, desa ini memiliki atraksi eko-agrowisata yang menarik seperti mengunjungi air terjun, mendaki puncak Sukma Ilang, hiking kebun kopi, coffee walk, pembibitan, pemeliharaan, dan panen kopi, kakao, pala, lada, dan cengkeh. Potensi edu-agrowisata perkebunan di Kelompok Tani Karya Subur disajikan pada Tabel 2 .

Destinasi agrowisata memerlukan dukungan kuliner dan oleh-oleh khas. Sajian kuliner khas antara lain buah durian jika sedang musim, minuman kopi dan kakao, air legen kelapa dan aren, dan kopi cincau. Oleh-oleh yang dapat dibeli pengunjung adalah buah durian, pisang, asinan pala, bubuk kopi Arabika, Robusta, dan Liberika, bubuk cokelat, gula merah serta bibit-bibit tanaman. Selain kelompok tani, produksi kuliner dan oleh-oleh harus melibatkan seluruh komponen masyarakat.

Kelompok Tani Karya Subur sering dikunjungi masyarakat yang terkait dengan keterlibatannya pada aktivitas agrowisata, eduwisata, ekowisata, dan desa wisata. Pengunjung yang ingin sekedar menyaksikan, belajar, atau magang terkait dengan keterampilan usaha perkebunan terutama kopi, kakao, dan pala sangat tepat berkunjung ke kelompok tani ini yang anggotanya sekaligus terlibat dan menginisiasi aktivitas sadar wisata, peramu wisata, dan pemandu wisata. Sebagian anggota kelompok merupakan petani muda kreatif, yang terampil menjelaskan, mendemonstrasikan, mengajari dan mendiskusikan berbagai keterampilan khususnya terkait usaha tani kopi dan kakao sejak dari pembibitan, penanaman, pemeliharaan, panen dan pascapanen, pengolahan, dan barista kopi. Sebagian petani muda berminat pada usaha tani produksi kopi dari hulu ke hilir, mampu mengadopsi agroteknologi kopi seperti mencoba berbagai varietas kopi Arabika, melakukan grafting kopi intra dan interspesies kombinasi dengan pemangkasan dan pemupukan yang tepat, panen petik merah, membuat mesin roasting sendiri, memproduksi kopi sangrai dan kopi bubuk, menguasai keterampilan barista, membuka kafe tenda di desa dan sekitarnya, di berbagai pameran dan kegiatan wisata. Ini adalah model penguatan kelompok tani melalui kapasitasnya dalam berproduksi dari hulu ke hilir sekaligus berperan sebagai kelompok sadar wisata. Umumnya pengembangan agrowisata dikaitkan dengan desa wisata seperti dilaporkan Gunawan et al. (2016) dan ekowisata seperti dilaporkan oleh Dwiridotjahjono et al. (2017).

Informasi adanya berbagai potensi dan keterampilan yang dimiliki anggota kelompok tani cepat menyebar terutama di lembaga pendidikan seperti Universitas Lampung yang dalam 5 tahun terakhir aktif mengirim mahasiswa untuk KKN dan magang serta dosen melakukan pembinaan desa melalui kegiatan PKM di Desa Pesawan Indah yang kemudian dari desa ini terbentuk desa definitif baru yaitu Desa Harapan Jaya. Kegiatan KKN dan magang di desa dan di kelompok tani meningkatkan wawasan dan keterampilan petani di bidang agroteknologi kopi, kakao, dan pala.

Pengembangan kopi Arabika di Desa Harapan Jaya dan sekitarnya memberikan nilai tambah tersendiri bagi kegiatan kelompok tani dengan berdatangan anggota kelompok tani lain dari berbagai wilayah di Lampung untuk belajar berusahatani kopi Arabika karena 98\% produksi

Tabel 2 Potensi edu-agrowisata perkebunan di Kelompok Tani Karya Subur

\begin{tabular}{|c|c|}
\hline Agrowisata & Uraian \\
\hline Fasilitas & $\begin{array}{l}\text { Homestay, kafe, kafe tenda, coffee shop, kebun pembibitan, kebun entres kakao (10 } \\
\text { klon), perkebunan kakao, pala, kopi Robusta, kopi Arabika ( } 4 \text { varietas), kopi Liberika, } \\
\text { pengolahan kopi, dan kakao }\end{array}$ \\
\hline $\begin{array}{l}\text { Pelatihan/praktik/ } \\
\text { Magang/KKN/studi } \\
\text { wisata/penelitian }\end{array}$ & $\begin{array}{l}\text { Budi daya dan pengolahan kakao, kopi, dan pala, mulai dari pengenalan varietas, } \\
\text { pembibitan, penyambungan, pemangkasan, pemupukan, panen, pascapanen, dan } \\
\text { pengolahan hasil }\end{array}$ \\
\hline Atraksi demo & $\begin{array}{l}\text { Penyambungan (kopi dan kakao) bibit dan rejuvenasi, petik buah (kopi, kakao, dan } \\
\text { pala), penyangraian kopi, pengolahan cokelat, barista kopi, dan uji citarasa kopi }\end{array}$ \\
\hline Atraksi coffee walk & $\begin{array}{l}\text { 1) Coffee walk destinasi air terjun Sinar Tiga; 2) Coffee walk destinasi puncak Sukma } \\
\text { Ilang; dan 3) Coffee walk destinasi air terjun Batu Perahu. }\end{array}$ \\
\hline
\end{tabular}


kopi Lampung adalah kopi Robusta. Tabel 3 menunjukkan mahasiswa dan dosen Universitas Lampung yang mendominasi kunjungan agrowisata ke Kolompok Tani Karya Subur, yaitu dari 116 orang pengunjung di tahun 2019, terdapat $58,6 \%$ berasal dari sivitas akademika Universitas Lampung. Memasuki tahun 2020 kunjungan dari lembaga sosial dan komunitas termasuk kelompok tani mengalami peningkatan yang signifikan yang menunjukkan bahwa aktivitas kelompok tani semakin dikenal di masyarakat. Kunjungan mahasiswa KKN yang terkait langsung dengan kelompok tani, penelitian atau magang akan diikuti dengan menginap di rumah-rumah anggota kelompok selama beberapa minggu sehingga secara rata-rata lama kunjungan mencapai 4 hari. Peningkatan kelompok pengunjung ini, yaitu mahasiswa yang berpraktek sangat potensial untuk meningkatkan lama kunjungan.

Kalender kedatangan pengunjung ke kelompok tani relatif menyebar sepanjang tahun. Hal ini didukung relatif menyebarnya kalender agrowisata di wilayah tersebut terkait dengan musim bunga, buah, dan panen kopi, kakao, dan pala. Musim panen buah tropis berlangsung di awal tahun akan diikuti dengan musim buah dan panen kopi, kakao, dan pala di antara kuartal pertama sampai kedua, kemudian adanya musim kopi berbunga pada kuartal ketiga. Kunjungan praktik ataupun penelitian yang terkait dengan kalender musim tanaman tertentu maka kunjungan harus menyesuaikan dengan kalender sebagaimana disajikan pada Tabel 4. Atraksi agrowisata yang menarik umumnya terkait dengan musim buah dan panen kopi.

Masih banyak kendala dan perbaikan yang diperlukan untuk mendorong pengembangan agrowisata yang dimotori oleh kelompok tani. Kendala utama pengembangan agrowisata adalah masalah aksesibilitas dan fasilitas. Sedangkan atraksi wisata sudah tersedia secara alami dari potensi alam dan pertanian. Agrowisata perkebunan umumnya terkait dengan wisata alam dan desa wisata serta sangat penting dalam kerangka sistem pertanian berkelanjutan (Evizal \& Prasmatiwi 2011). Air terjun Sinar Tiga yang

Tabel 3 Kunjungan agrowisata di kelompok tani periode 2019/2020

\begin{tabular}{llrr}
\hline \multicolumn{1}{c}{ Periode } & \multicolumn{1}{c}{ Kategori pengunjung } & Jumlah (orang) & Hari x orang \\
\hline Jan-April 2019 & Unila & 15 & 15 \\
& Lembaga pendidikan lain & 2 & 2 \\
& Lembaga profesi & 10 & 10 \\
Mei-Agustus 2019 & Lembaga sosial/komunitas & 0 & 0 \\
& Unila & 21 & 311 \\
& Lembaga pendidikan lain & 2 & 10 \\
& Lembaga profesi & 10 & 5 \\
September-Desember 2019 & Lembaga sosial/komunitas & 5 & 26 \\
& Unila & 32 & 150 \\
Januari-Februari 2020 & Lembaga pendidikan lain & 5 & 16 \\
& Lembaga profesi & 16 & 0 \\
& Lembaga sosial/komunitas & 0 & 19 \\
& Unila & 7 & 85 \\
& Lembaga pendidikan lain & 13 & 0 \\
\hline Jumlah & Lembaga profesi & 0 & 35 \\
\hline
\end{tabular}

Tabel 4 Kalender agrowisata di Way Ratai Pesawaran

\begin{tabular}{|c|c|c|c|c|c|c|c|c|c|c|c|c|}
\hline Jadwal agrowisata & Jan & Feb & Mar & Apr & Mei & Jun & Jul & Ags & Sep & Okt & Nov & Des \\
\hline \multicolumn{13}{|l|}{ Kopi berbunga } \\
\hline \multicolumn{13}{|l|}{ Panen kopi Robusta } \\
\hline \multicolumn{13}{|l|}{ Panen kopi Arabika } \\
\hline \multicolumn{13}{|l|}{ Panen kakao } \\
\hline \multicolumn{13}{|l|}{ Panen pala } \\
\hline \multicolumn{13}{|l|}{ Musim durian } \\
\hline \multicolumn{13}{|l|}{ Musim duku } \\
\hline \multicolumn{13}{|l|}{ Musim rambutan } \\
\hline Musim manggis & & & & & & & & & & & & \\
\hline
\end{tabular}


berlokasi di desa Harapan Jaya harus dicapai 30 menit dari lokasi parkir. Air terjun Banyu Mandiri atau Curup Mandiri terdiri dari dua air terjun yang berbeda tempat semuanya berlokasi di Desa Pesawaran Indah namun dapat diakses dari Desa Harapan Jaya. Curup Mandiri 1 sudah dikelola untuk wisata jika diakses melalui wilayah Desa Pesawaran Indah harus melalui jalan yang terjal. Air terjun Curup Mandiri 2 atau Curup Batu Perahu belum dikelola karena belum ada jalan. Air terjun ini lebih lebih mudah diakses dari Desa Harapan Jaya sehingga ke depan perlu kerja sama antara kedua desa untuk membuat akses jalan yang dapat dilewati sepeda motor dan mengelolanya secara bersama antar kelompok sadar wisata kedua desa.

Tabel 5 menyajikan kendala dan perbaikan yang diperlukan untuk pengembangan aktivitas agrowisata di desa tersebut. Fasilitas perlu terus ditingkatkan yang melibatkan lingkup yang lebih luas yaitu lingkup desa sehingga perlu dirembug di tingkat desa agar mendapat dukungan dana desa serta dapat dikaitkan dengan usaha Bumdes. Selain fasilitas maka kapasitas anggota kelompok tani perlu terus ditingkatkan misalnya sikap dan kemampuan berkomunikasi terkait teknis produksi kopi, kakao, dan pala dari hulu ke hilir, promosi, pemandu wisata, serta pelayanan home stay. Hal ini sesuai pendapat Ciolac et al. (2019) bahwa agrowisata merupakan aktivitas yang kompleks dalam pembangunan, sosial, budaya, dan ekonomi pedesaan terutama di wilayah pegunungan sehingga memerlukan peningkatan kapasitas masyarakat terkait mentalitas dan profesionalisme dalam pelayanan agrowisata. Zhang \& Lei (2012) melaporkan bahwa sikap, pengetahuan dan partisipasi penting untuk mendorong perkembangan wisata.

\section{SIMPULAN}

Kegiatan PKM ini meningkatkan pengetahuan dan keterampilan anggota kelompok tani dalam agroteknologi kopi Arabika, yaitu dari 12 indikator pengetahuan/keterampilan menunjukkan peningkatan skor 36 menjadi 51. Kegiatan PKM ini meningkatkan produktivitas kebun kopi demplot yang didampingi dari 0,6 menjadi 1,1 ton/ha. Model penguatan kelompok tani berbasis agrowisata kopi adalah melalui 4 pilar, yaitu: a) Peningkatan produktivitas kopi; b) Peningkatan kapasitas kelompok dalam aktivitas eduwisata dan desawisata terkait dengan proses produksi kopi dari hulu ke hilir; c) Peningkatan aksesibilitas dan fasilitas yang dikoordinasikan dengan aparat desa; dan d) Peningkatan promosi agrowisata khususnya kepada lembaga pendidikan, profesi, dan komunitas.

\section{UCAPAN TERIMA KASIH}

Penulis mengucapkan terima kasih kepada Lembaga Penelitian dan Pengabdian Kepada Masyarakat (LPPM) Universitas Lampung atas dana Pengabdian DIPA BLU Universitas Lampung Skema Pengabdian Unggulan Tahun 2019.

\section{DAFTAR PUSTAKA}

BPS Kabupaten Pesawaran. 2018. Kabupaten Pesawaran Dalam Angka 2018. Gedung Tataan.

Ciolac R, Adamov T, Lancu T, Popescu G, Lile R, Rujescu C, Marin D. 2019. Agritourism a sustainable development factor for improving

Tabel 5 Perbaikan yang diperlukan

\begin{tabular}{|c|c|}
\hline Perbaikan & Uraian \\
\hline Aksesibilitas & $\begin{array}{l}\text { Akses jalan ke kebun, air terjun, dan puncak Sukma Ilang relatif buruk. Jalan yang ada } \\
\text { ke air terjun dari tempat parkir masih harus dilanjutkan dengan berjalan kaki. }\end{array}$ \\
\hline Fasilitas homestay & $\begin{array}{l}\text { Rumah petani anggota kelompok perlu perbaikan terutama kamar tidur dan kamar } \\
\text { mandi }\end{array}$ \\
\hline Fasilitas pertemuan & Belum ada balai pertemuan khusus untuk menerima tamu \\
\hline Fasilitas parkir & Belum ada tempat parkir khusus terutama untuk bus \\
\hline Menu masakan & $\begin{array}{l}\text { Perlu diperkaya masakan tradisional berbahan lokal seperti buntil, botok, tumis } \\
\text { bunga papaya, pecel bunga turi, dan sup jamur }\end{array}$ \\
\hline Oleh-oleh & $\begin{array}{l}\text { Harus selalu tersedia produk bubuk kopi Robusta, Arabika, Liberika, bubuk kakao, } \\
\text { asinan, dan manisan pala. }\end{array}$ \\
\hline Promosi & $\begin{array}{l}\text { Perlu dibangun website berisi semua informasi terkait agrowisata, ekowisata, dan } \\
\text { desa wisata setempat }\end{array}$ \\
\hline
\end{tabular}


the 'health' of rural settlements, case study Apuseni Mountains Area. Sustainability. 11(1467): 1-24. https://doi.org/10. $3390 /$ su11051467

Dwiridotjahjono J, Arifin AZ, Sasongko PE, Maroeto, Santoso W. 2017. Pengembangan agroekowisata berbasis perkebunan kopi rakyat di Kecamatan Tutur, Kabupaten Pasuruan. Agrokreatif Jurnal Ilmiah Pengabdian Kepada Masyarakat. 3(2): 157165. https://doi.org/10.29244/agrokreatif. 3.2.157-165

Evizal R. 2013. Etno-agronomi pengelolaan perkebunan kopi di Sumberjaya Kabupaten Lampung Barat. Jurnal Agrotrop. 3(2): 1-12.

Evizal R, Prasmatiwi FE. 2011. Agrotourism potential and sustainable agriculture in Lampung. In: Proceeding International Seminar on Agro-tourism Development (ISAD). Yogyakarta (ID): 6-8 ${ }^{\text {th }}$ December 2011.

Evizal R, Prasmatiwi FE. 2020. Agroteknologi kopi grafting untuk peningkatan produksi. Jurnal Agrotek Tropika. 8(3): 423-434. https: //doi.org/10.23960/jat.v8i3.4088

Gunawan W, Yunita D, Zakaria S. 2016. Pengembangan wisata kopi berbasis masyarakat di Desa Warjabakti Kabupaten Bandung. Sosioglobal Jurnal Pemikiran dan Penelitian Sosiologi. 1(1): 33-48. https://doi. org/10.24198/jsg.v1i1.11184

Gusti AI, Haryono D, Prasmatiwi FE. 2013. Pendapatan rumah tangga petani kakao di Desa Pesawaran Indah, Kecamatan Padang Cermin, Kabupaten Pesawaran. Jurnal IlmiIlmu Agribisnis. 1(4): 278-283.
Hilmanto R. 2011. Adaptasi dan interaksi hasil pemahaman masyarakat Dusun Lubuk Baka terhadap alam dalam pengelolaan agroforestri. Forum Ilmiah Jurnal Bunga Rampai. 8(1): 72-82.

Hermanto, Swatika DKS. 2011. Penguatan kelompok tani: Langkah awal peningkatan kesejahteraan petani. Analisis Kebijakan Pertanian. 9(4): 371-390. https://doi.org/ 10.21082/akp.v9n4.2011.371-390

Mayasari T, Nugroho B, Wijayanto N. 2015. Perubahan kelembagaan formal dalam pengelolaan lahan di blok pemanfaatan Taman Hutan Raya Wan Abdul Rachman (Tahura WAR). Risalah Kebijakan Pertanian dan Lingkungan. 2(1): 77-85. https://doi.org/ 10.20957/jkebijakan.v2i1.10398

Miswar D, Sugiyanta IG, Halengkara L. 2018. Analisis spasial potensi Desa Harapan Jaya Kecamatan Way Ratai Kabupaten Pesawaran Propinsi Lampung. Jurnal Geografi. 7(1): 1-18. https://doi.org/10.24036/geografi/vol7iss $1 / 437$

Mustofa D, Asyik B, Miswar D. 2018. Aksesibilitas objek wisata air terjun Sinar Tiga di Desa Harapan Jaya tahun 2018. Jurnal Penelitian Geografi. 6(4): 1-14.

Pemkab Pesawaran. 2017. Potensi Kecamatan Way Ratai. Diunduh 18 Maret 2020. Tersedia pada https://www.pesawarankab.go.id/ halaman-423-potensi-kecamatan-wayratai.html

Zhang H, Lei SL. 2012. A structural model of resident's intention to participate in ecotourism: The case of wetland community. Tourism Management. 33: 916-925. https:// doi.org/10.1016/j.tourman.2011.09.012 